\title{
Acute serum amyloid $A$ is an endogenous TLR2 ligand that mediates inflammatory and angiogenic mechanisms
}

\author{
Mary Connolly, ${ }^{1}$ Peter R Rooney, ${ }_{1}$ Trudy McGarry, ${ }_{1}^{1}$ Ashwini X Maratha, ${ }^{2}$ \\ Jennifer McCormick, ${ }^{1}$ Sinead M Miggin, ${ }^{2}$ Douglas I Veale, ${ }^{1}$ Ursula Fearon ${ }^{1}$
}

\begin{abstract}
Handling editor Tore K Kvien
- Additional material is published online only. To view please visit the journal online (http://dx.doi.org/10.1136/ annrheumdis-2015-207655)

${ }^{1}$ Centre for Arthritis and Rheumatic Diseases, Dublin Academic Medical Centre and Conway Institute of

Biomolecular and Biomedical Research, Dublin 4, Ireland

${ }^{2}$ Department of Biology, Institute of Immunology, National University of Ireland Maynooth, Maynooth, County Kildare, Ireland
\end{abstract}

\section{Correspondence to}

Dr Ursula Fearon, Centre for Arthritis and Rheumatic

Diseases, Dublin Academic Medical Centre, St. Vincent's University Hospital, Dublin 4 Ireland; ursula.fearon@ucd.ie

Received 25 March 2015 Revised 30 July 2015 Accepted 1 August 2015 Published Online First 19 August 2015
CrossMark

To cite: Connolly $M$ Rooney PR, McGarry T, et al. Ann Rheum Dis

2016;75:1392-1398.

\section{ABSTRACT}

Introduction Acute-phase serum amyloid A (A-SAA) has cytokine-like properties and is expressed at sites of inflammation. We examined whether A-SAA-induced pro-inflammatory mechanisms are mediated through Toll-like receptor 2 (TLR2) in rheumatoid arthritis (RA). Methods The effect of A-SAA on human embryonic kidney (HEK), TLR2 or TLR4 cells was quantified by nuclear factor (NF)- $\kappa B$ luciferase reporter assays. A-SAAinduced RASFC and dHMVEC function were performed in the presence of a specific neutralising anti-TLR2 mAb (OPN301) $(1 \mu \mathrm{g} / \mathrm{mL}$ ) and matched lgG isotype control Ab $(1 \mu \mathrm{g} / \mathrm{mL})$. Cell surface expression of intracellular adhesion molecule (ICAM)-1, chemokine expression, cell migration, invasion and angiogenesis were assessed by flow cytometry, ELISA, Matrigel invasion chambers and tube formation assays. MyD88 expression was assessed by real-time PCR and western blot.

Results A-SAA induced TLR2 activation through induction of NF- $\kappa B(p<0.05)$, but failed to induce NF- $\kappa B$ in HEK-TLR4 cells, confirming specificity for TLR2. A-SAA-induced proliferation, invasion and migration were significantly inhibited in the presence of anti-TLR2 (all $p<0.05$ ), with no significant effect observed for tumour necrosis factor- $\alpha$-induced events. Additionally, A-SAA-induced ICAM-1, interleukin-8, monocyte chemoattractant protein-1, RANTES and GRO- $\alpha$ expression were significantly reduced in the presence of anti-TLR2 (all $p<0.05$ ), as was A-SAA induced angiogenesis $(p<0.05)$. Finally, A-SAA induced MyD88 signalling in RASFC and dHMVEC $(p<0.05)$.

Conclusions A-SAA is an endogenous ligand for TLR2, inducing pro-inflammatory effects in RA. Blocking the ASAA/TLR2 interaction may be a potential therapeutic intervention in RA.

\section{INTRODUCTION}

Rheumatoid arthritis (RA) is an autoimmune disease characterised by synovial proliferation, neovascularisation and leucocyte extravasation. ${ }^{1} 2$ Activation of the synovium transforms the lining layer into a hyperplastic tumour-like 'pannus' that is capable of destroying adjacent articular cartilage and bone. ${ }^{3-5}$ Acute-phase serum amyloid A (A-SAA) is an acute-phase protein that belongs to a closely related group of $12-14 \mathrm{kDa}$ apoproteins. ${ }^{6} 7$ During the inflammatory response, A-SAA is dramatically elevated in serum where it displaces ApoA-1 and saturates high-density lipoprotein (HDL) ${ }^{8}$ resulting in high levels of free circulating
A-SAA. ${ }^{9}$ Unlike other acute-phase proteins that are synthesised primarily in the liver as part of the systemic acute-phase response, A-SAA expression is markedly increased at local sites of tissue inflammation. ${ }^{10}$ Such extra-hepatic A-SAA expression has been demonstrated in brain amyloid plaques of patients with Alzheimer's disease and in atherosclerotic lesions. ${ }^{11}{ }^{12} \mathrm{~A}-\mathrm{SAA}$ is also the precursor of $\mathrm{AA}$, an insoluble degradation product, deposited in a number of major organs in the progressive fatal disease secondary amyloidosis. ${ }^{13}$

We and others have previously reported significantly increased expression of A-SAA and its receptors in RA synovial tissue and cells compared with OA and healthy controls. ${ }^{14-17}$ Furthermore, A-SAA is spontaneously released from RA synovial tissue explants, with A-SAA levels at site of inflammation significantly higher than systemic circulation, ${ }^{14}$ and A-SAA induces chemokines, adhesion molecules, angiogenesis, cytoskeletal rearrangement and matrix metalloproteinases (MMPs) in RA synovial cells in vitro. ${ }^{17-22}$ Furthermore, A-SAA has a high affinity for the extracellular matrix components and promotes RASFC fibroblasts invasion through a $\beta 1$-integrin and RhoGTPase-dependent mechanism. $^{22}$ A-SAA has two well-characterised receptors, lipoxin $\mathrm{A}_{4}$ receptor/N-formyl peptide receptor-like-1 (FPRL-1) and Scavenger receptor class B member 1 (SR-B1) (formerly CD36 and LIMPII analogous-1 (CLA-1)) both highly expressed in RA ST compared with OA or healthy control. $^{16} 19 \quad 24$ Through FPRL-1 and SR-B1, A-SAA activates many pro-inflammatory processes, including cell migration/invasion, chemokine induction and MMP production. ${ }^{16}$ 25-28 Blockade of FRPL-1 and SR-B1 in an ex vivo RA synovial explant culture model inhibits spontaneous chemokine secretion, suggesting endogenous A-SAA is active. $^{14}$

Recent evidence has implicated Toll-like receptor 2 (TLR2) as an alternative receptor for A-SAA, ${ }^{29}$ TLR2 is expressed in the perivascular regions of the joint, ${ }^{30}$ at the sites of attachment and invasion into cartilage and bone, and on synovial macrophages. ${ }^{31}$ Increased expression of TLR2 has been demonstrated in collagen-induced arthritis. ${ }^{32}$ Additionally, overexpression of dominant negative forms of TLR2/4 adapter molecules MyD88 and $\mathrm{Mal} / \mathrm{TIRAP}$ or anti-TLR2 blockade inhibits spontaneous release of pro-inflammatory cytokines from RA synovial cells and explants. ${ }^{33} 34$ 
In this study, we examine whether TLR2 mediates A-SAA-induced pro-inflammatory mechanisms in RA. The rapid induction of A-SAA during inflammation, its localised expression at inflammatory sites and its ability to induce many pro-inflammatory processes through TLR2 suggest that A-SAA is directly involved in the pathogenesis of inflammatory joint disease.

\section{MATERIALS AND METHODS}

\section{Arthroscopy, isolation of RA synovial fibroblasts and reagents}

See online supplementary file 1.

\section{Luciferase reporter gene assay}

HEK293-TLR2 and HEK293-TLR4 cells were grown in Dulbecco's modified Eagle medium with GlutaMAX (Gibco-BRL) supplemented with $10 \%$ fetal calf serum (FCS), penicillin-streptomycin, noromycin and $200 \mu \mathrm{g} / \mathrm{mL}$ of G418 and maintained at $37^{\circ} \mathrm{C}$ in a humidified atmosphere of $5 \% \mathrm{CO}_{2}{ }^{36}$ HEK293-TLR2 and HEK293-TLR4 cells $\left(2 \times 10^{4}\right.$ cells/well; 96-well plate) were transfected with $80 \mathrm{ng} / \mathrm{well}$ luciferase reporter gene plasmid for nuclear factor (NF)-kB, ${ }^{37}$ using Lipofectamine 2000 as described by the manufacturer (Invitrogen). In all cases, $40 \mathrm{ng} /$ well of phRL-TK reporter gene was co-transfected to normalise data for transfection efficiency. After $24 \mathrm{~h}$, cells were stimulated with A-SAA $(0.01-10 \mu \mathrm{g} / \mathrm{mL})$, $\mathrm{Pam}_{2} \mathrm{CSK}_{4}(1 \mu \mathrm{g} / \mathrm{mL}), \mathrm{Pam}_{3} \mathrm{CSK}_{4}(1 \mu \mathrm{g} / \mathrm{mL})$ or lipopolysaccharide (LPS) $(0.01-10 \mu \mathrm{g} / \mathrm{mL})$ for $24 \mathrm{~h}$. Cell lysates were prepared and reporter gene activity was measured using the Dual Luciferase Assay system (Promega) as previously described. ${ }^{38}$ Data are expressed as the mean fold induction \pm SEM relative to control levels from a minimum of three separate experiments.

\section{Human microvascular endothelial cell culture and cell growth assays}

See online supplementary file 1 .

\section{dHMVEC tubule formation in vitro}

Matrigel $(50 \mu \mathrm{L})$ (Becton Dickinson, Mountain View, California, USA) was plated in 48-well culture plates after thawing on ice and allowed to polymerise for $1 \mathrm{~h}$ at $37^{\circ} \mathrm{C}$ in humidified air with 5\% $\mathrm{CO}_{2}$. dHMVEC were removed from culture, trypsinised and resuspended at a concentration of $4 \times 10^{4}$ cells $/ \mathrm{mL}$ in EGM. In total, $500 \mu \mathrm{L}$ of cell suspension was added to each chamber in the presence of A-SAA $(10 \mu \mathrm{g} / \mathrm{mL})$, tumour necrosis factor $\quad(\mathrm{TNF})-\alpha \quad(10 \mathrm{ng} / \mathrm{mL}) \pm \mathrm{OPN} 301 \quad(1 \mu \mathrm{g} / \mathrm{mL}), \quad$ or IgG-matched control $(1 \mu \mathrm{g} / \mathrm{mL})$. The chambers were then incubated for $24 \mathrm{~h}$ at $37^{\circ} \mathrm{C}$ in humidified air with $5 \% \mathrm{CO}_{2}$. Endothelial cell tubule formation was assessed using phasecontrast microscopy and quantified as previously described. ${ }^{18}$

\section{Analysis of cell surface ICAM-1 expression}

RASFC or dHMVEC were plated to a density of $5 \times 10^{4}$ in 12-well plates (Falcon, Franklin Lakes, New Jersey, USA) for 48 $\mathrm{h}$ in medium plus supplements. Cells were stimulated with A-SAA $(10 \mu \mathrm{g} / \mathrm{mL}) \pm \mathrm{OPN} 301(1 \mu \mathrm{g} / \mathrm{mL})$ for $6 \mathrm{~h}$, then incubated with $0.3 \mu \mathrm{g} / \mathrm{mL}$ of phycoerythrin-conjugated mouse monoclonal anti-intracellular adhesion molecule (ICAM)-1 or isotypematched IgG control (Becton Dickinson) for $30 \mathrm{~min}$ at $4^{\circ} \mathrm{C}$. Cells were then washed twice and fixed in $1 \%$ paraformaldehyde, and analysed by flow cytometry (FACS) using a FACScan flow cytometer and Lysis II software (both from Becton Dickinson).

\section{Cytokine measurement in RASFC and dHMVEC}

To assess the effect of TLR2 blockade on chemokine expression, RASFC and dHMVEC were serum starved for $24 \mathrm{~h}$, followed by stimulation with A-SAA $(10 \mu \mathrm{g} / \mathrm{mL})$ in the presence or absence of OPN301 $(1 \mu \mathrm{g} / \mathrm{mL})$ for a further $24 \mathrm{~h}$. Supernatants were harvested and protein levels of interleukin (IL)-8, monocyte chemoattractant protein (MCP)-1, IL-6, RANTES and GRO- $\alpha$ were measured by ELISA (R\&D Systems) according to the manufacturer's protocol.

\section{Wound repair assay}

RASFC and dHMVEC were plated in 48-well plates, grown to confluency, growth arrested for $24 \mathrm{~h}$ in serum-free Roswell Park Memorial Institute medium or 1\% EGM and scraped with a sterile pipette tip to create a linear wound across the well. Cells were subsequently stimulated for $24 \mathrm{~h}$ with A-SAA $(10 \mu \mathrm{g} / \mathrm{mL})$ and TNF- $\alpha(10 \mathrm{ng} / \mathrm{mL})$ in the presence or absence of OPN301 $(1 \mu \mathrm{g} / \mathrm{mL})$ or isotype-matched $\mathrm{IgG}(1 \mu \mathrm{g} / \mathrm{mL})$ control antibody. Migration was determined by visual assessment of cells that had repopulated wound margins using phase-contrast microscopy.

\section{Transwell invasion assay}

Biocoat Matrigel Invasion Chambers (Becton Dickinson, UK) were used to assess cell invasion in response to A-SAA \pm OPN301. dHMVEC were seeded at a density of $2.5 \times 10^{4}$ per well on $8 \mu \mathrm{m}$ membranes pre-coated with Matrigel. EGM containing A-SAA $(10 \mu \mathrm{g} / \mathrm{mL})$ or TNF- $\alpha(10 \mathrm{ng} / \mathrm{mL})$ in the presence or absence of OPN301 $(1 \mu \mathrm{g} / \mathrm{mL})$ or IgG-matched control antibody was added to the lower wells. Cells were allowed to migrate for $24 \mathrm{~h}$ in EGM media containing 1\% FCS. Migrating cells attached to the lower membrane were fixed with $1 \%$ glutaraldehyde and stained with $0.1 \%$ crystal violet. To assess the average number of migrating cells, cells were counted in five random high-power fields.

\section{RNA extraction from RASFC and dHMVEC}

RASFC and dHMVEC were stimulated with A-SAA $(10 \mu \mathrm{g} / \mathrm{mL})$ or TNF- $\alpha(10 \mathrm{ng} / \mathrm{mL})$ in serum-free medium for $3-24 \mathrm{~h}$ prior to RNA extraction using an RNeasy Mini Kit according to the manufacturer's protocol (Qiagen, Crawley, UK). The integrity of RNA samples was assessed using a bioanalyzer (Agilent Technologies, Cork, Ireland). Samples with a 260:280 nm ratio of $\geq 1.8$ and an RNA Integrity Number between 7 and 10 were used in subsequent experiments. Isolated RNA was stored at $-80^{\circ} \mathrm{C}$ until further use.

\section{RT-PCR}

Total RNA $(1 \mu \mathrm{g})$ was added to a $25 \mu \mathrm{L}$ reaction volume containing $200 \mathrm{U}$ Superscript II in reverse transcriptase buffer $100 \mathrm{mM}$ dithiothreitol (supplied with RT-enzyme), 40 units RNasin Ribonuclease Inhibitor (Promega, Dublin, Ireland), $1.25 \mathrm{mM}$ each of dATP, dCTP, dGTP and dTTP (Promega), RNase-free water and $500 \mathrm{ng}$ of oligo dTs (Promega). Reverse transcription was performed at $42^{\circ} \mathrm{C}$ for $50 \mathrm{~min}$. The reaction was terminated by incubation at $95^{\circ} \mathrm{C}$ for $15 \mathrm{~min}$. PCR primers and probes for MyD88, GAPDH and $\beta$-actin (endogenous controls) were designed by Applied Biosystems (Assays-on-Demand, Applied Biosystems). Amplification reactions contained $1 \mu \mathrm{L}$ cDNA, $12.5 \mu \mathrm{L}$ of Universal Taqman 2X PCR Mastermix (Applied Biosystems, Cheshire, UK), $1.25 \mu \mathrm{L}$ of primer and probe mix and were brought to a total volume of $25 \mu \mathrm{L}$ by the addition of RNase-free water. All reactions/negative controls were performed in triplicate using 96-well plates on the Roche 
LC480 (Roche Diagnostics, West Sussex, UK). Relative changes in gene expression were determined using the $C_{t}$ method.

\section{Western blot for MyD88}

RASFC and dHMVEC were incubated with A-SAA $(10 \mu \mathrm{g} / \mathrm{mL})$ or TNF- $\alpha(10 \mathrm{ng} / \mathrm{mL})$ for $15 \mathrm{~min}$ prior to lysis. Cell lysates were separated by SDS-PAGE and transferred onto nitrocellulose membranes. Western blotting was performed using an anti-MyD88 rabbit polyclonal AbMyD88 (Abcam, Cambridge, UK) according to the manufacturer's protocol. Blots were developed using ECL (Pierce, Rockford, Illinois, USA) for detection of horseradish peroxidase (HRP).

\section{Statistical analysis}

Statistical analysis was performed using SPSS 11 for Windows (SPSS, Chicago, Illinois, USA). For comparisons between treated and untreated RASFC, non-parametric Wilcoxon signed-rank test for paired samples was performed. Parametric Student's $t$ tests were used for analysis of dHMVEC and HEK293 cell data. A $p$ value of $<0.05$ was considered significant.

\section{RESULTS}

\section{TLR2 is a functional receptor for A-SAA}

The ability of A-SAA to drive TLR2-mediated NF- $\mathrm{BB}$ induction was investigated using $\mathrm{NF}-\kappa \mathrm{B}$ luciferase reporter gene assays. A-SAA induced TLR2-mediated NF- $\kappa$ B luciferase reporter gene activity in a dose-dependent manner with maximum activity observed at 10 and $50 \mu \mathrm{g} / \mathrm{mL}$ (see online supplementary figure S1A). A-SAA induced a 15.7-fold increase $(10 \mu \mathrm{g} / \mathrm{mL})$ or 14.6-fold increase $(50 \mu \mathrm{g} / \mathrm{mL})$ in TLR2-mediated NF- $\kappa$ B luciferase reporter gene activity compared with control $(p<0.05)$ (figure 1A). Additionally, TLR2-mediated NF-kB luciferase
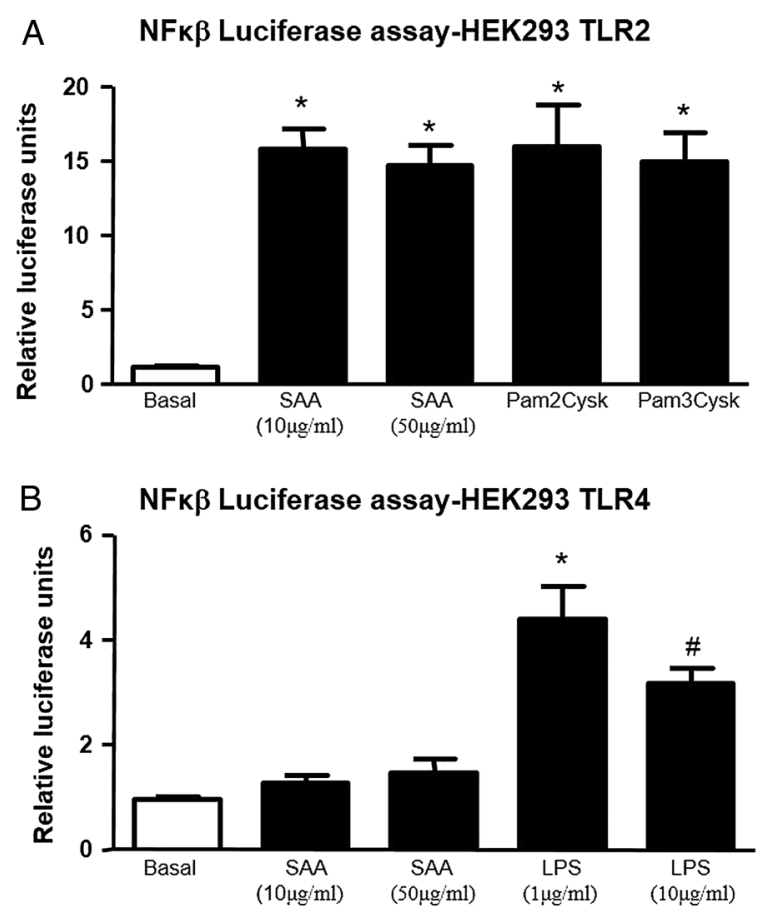

Figure 1 Acute-phase serum amyloid A (A-SAA) is a functional ligand for Toll-like receptor 2 (TLR2). The effect of A-SAA on nuclear factor (NF)-kb luciferase reporter activity in (A) HEK293-TLR2 cells and (B) HEK293-TLR4 cells. Results are shown as the mean \pm SEM $(n=3)$. ${ }^{*} \mathrm{p}<0.01,{ }^{\#} \mathrm{p}<0.05$ compared with basal control. LPS, lipopolysaccharide. reporter gene activity was significantly enhanced following stimulation with the TLR2 agonists, $\mathrm{Pam}_{2} \mathrm{CSK}_{4}$ and $\mathrm{Pam}_{3} \mathrm{CSK}_{4}$ $(\mathrm{p}<0.05)$. LPS-induced TLR4 mediated NF- $\mathrm{KB}$ reporter gene activity in a dose-dependent manner (see online supplementary figure S1B), with no effect observed for A-SAA (figure 1B).

\section{SAA-induced cell growth and angiogenesis is mediated via TLR2}

RASFC proliferation significantly increased by $314 \%$ following stimulation with A-SAA $(10 \mu \mathrm{g} / \mathrm{mL})(\mathrm{p}=0.02)$ and by $399 \%$ in response to TNF- $\alpha$ stimulation $(p=0.005)$ (see online supplementary figure S2A). A-SAA-induced cell growth was inhibited by $37.4 \%$ in the presence of OPN301, with no significant effect observed on TNF- $\alpha$-induced cell growth (see online supplementary figure S2A). Similar effects were observed in dHMVEC where anti-TLR2 significantly reduced A-SAA cell growth $(p=0.002)$ (figure $2 \mathrm{~B})$, but had no effect on TNF- $\alpha$ (see online supplementary figure S2A).

A significant increase in the formation of tube-like structures was demonstrated in the presence of A-SAA alone $(p<0.05)$ (figure 2C, D), an effect that was inhibited in the presence of OPN301 $(p<0.05)$. Figure 2C shows representative images of increased tube formation following A-SAA stimulation, as demonstrated by an increase in the number of connecting branches between two endothelial cells. This effect was inhibited to near basal in the presence of anti-TLR2.

\section{TLR2 mediates A-SAA-induced chemokine expression in RASFC and dHMVEC}

A-SAA significantly increased IL-6, IL-8, MCP-1, GRO- $\alpha$ and RANTES expression in both RASFC (figure $3 \mathrm{~A}$ ) and dHMVEC (figure $3 \mathrm{~B})(\mathrm{p}<0.05)$. Co-incubation of cells with $\mathrm{SAA}$ and OPN301 resulted in significant reductions in SAA-induced cytokine activity $(\mathrm{p}<0.05)$. In contrast, OPN301 had no effect on TNF- $\alpha$-induced cytokine production in either RASFC or dHMVEC (data not shown).

\section{TLR2 mediates A-SAA-induced adhesion, invasion and migration}

Figure 4A shows representative histograms demonstrating increased RASFC surface expression of ICAM-1 in response to A-SAA compared with basal control, an effect that was inhibited by OPN301 (figure 4A, i). A-SAA significantly increased RASFC ICAM-1 expression from a mean fluorescent intensity (MFI) of 24.71 \pm 5.44 to $88.27 \pm 18.68(\mathrm{p}<0.05)$, which was significantly reduced to $36.34 \pm 10.96$ in the presence of OPN301 (figure 4A, ii) $(p<0.05)$. Similarly, A-SAA significantly increased cell surface ICAM-1 expression on dHMVEC, from an MFI of $209.83 \pm 109.34$ to 724.58 $\pm 74.5(\mathrm{p}<0.05)$, an effect that was significantly inhibited by OPN301 to 255.49 ( $p<0.01$ ) (data not shown).

dHMVEC invasion was significantly induced by A-SAA compared with control (figure 4B), an effect similar to stimulation with TNF- $\alpha$. Blockade of TLR2 significantly decreased A-SAA-induced invasion $(\mathrm{p}<0.05)$ (figure $4 \mathrm{~B}, \mathrm{C}$ ), but had no effect on TNF- $\alpha$-induced invasion (see online supplementary figure S2B). Figure 4D shows representative images of wound repair where repopulation of wound margins was observed in response to A-SAA, an effect that was inhibited in the presence of OPN301.

\section{A-SAA induces MyD88 expression}

As all known effector functions of TLR2 signalling depend on the MyD88 adaptor protein, we next examined whether MyD88 could be induced by A-SAA. As shown in figure 5, A-SAA 
Figure 2 Acute-phase serum amyloid A (A-SAA)-induced cell growth and angiogenesis is Toll-like receptor 2 (TLR2) dependent. (A) Rheumatoid arthritis (RA) synovial fibroblasts (RASFC) and (B) microvascular endothelial cells (dHMVEC) were stimulated with SAA $(10 \mu \mathrm{g} / \mathrm{mL})$ in the presence or absence of OPN301 $(1 \mu \mathrm{g} /$ $\mathrm{mL}$ ) or IgG control $(1 \mu \mathrm{g} / \mathrm{mL})$ for $72 \mathrm{~h}$ and cell growth was assessed by crystal violet assay. (C) Representative photomicrographs of dHMVEC tubule formation on Matrigel matrix following $24 \mathrm{~h}$ of incubation with SAA $(10 \mu \mathrm{g} /$ $\mathrm{mL}) \pm$ OPN301 $(1 \mu \mathrm{g} / \mathrm{mL})$. Quantitative analysis of the number of connecting branches at baseline and in response to $A-S A A \pm$ OPN301 $(1 \mu \mathrm{g} / \mathrm{mL})$ or $\lg G$ $(1 \mu \mathrm{g} / \mathrm{mL})$ control shown in (D). The tube analysis was determined from five sequential fields (magnification $\times 40$ ) focusing on the surface of the Matrigel. Results are shown as the mean \pm SEM $(n=5-7)$. * $p<0.05$ significantly different.
A

RASFC

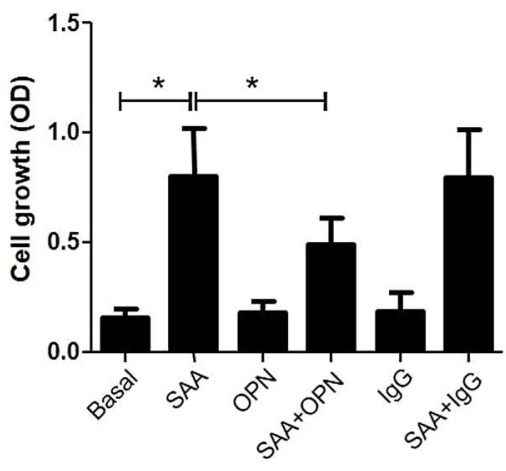

C

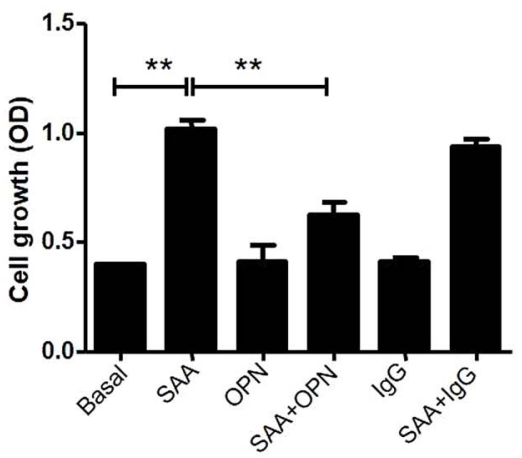

B
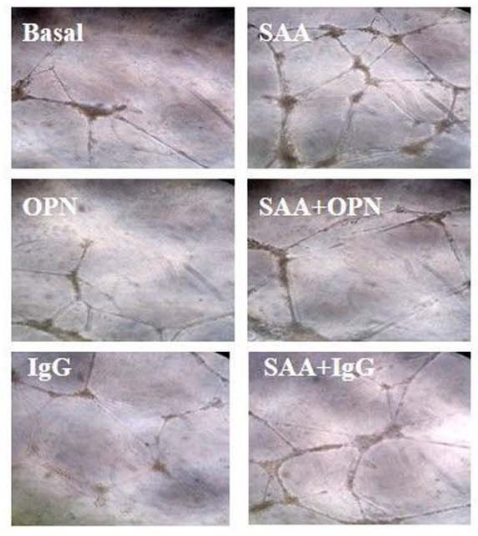

D

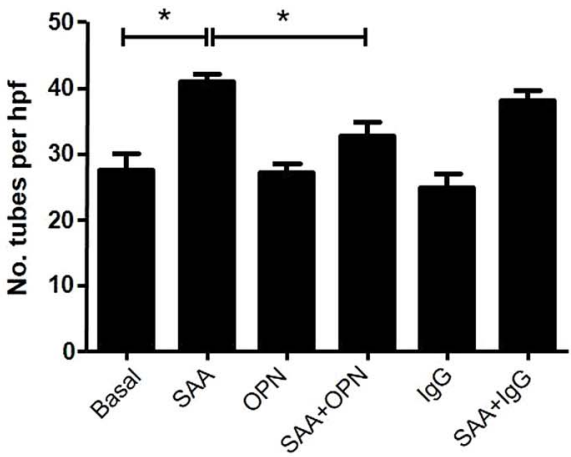

A

RASFC
B

dHMVEC
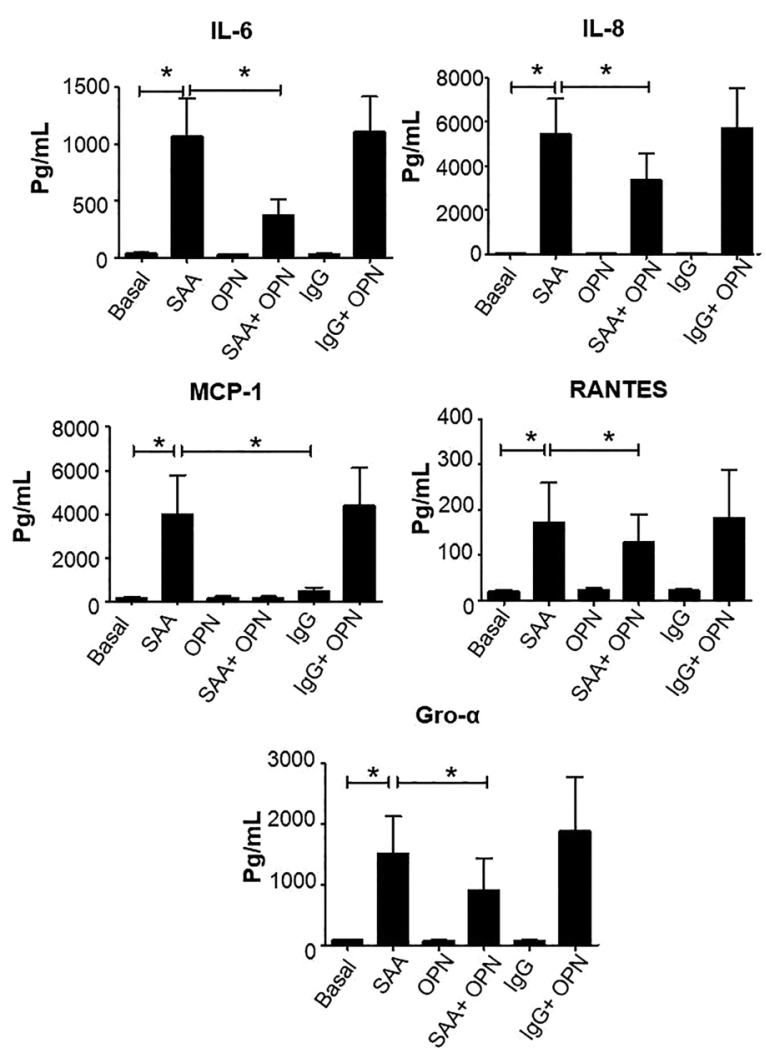

IL-6
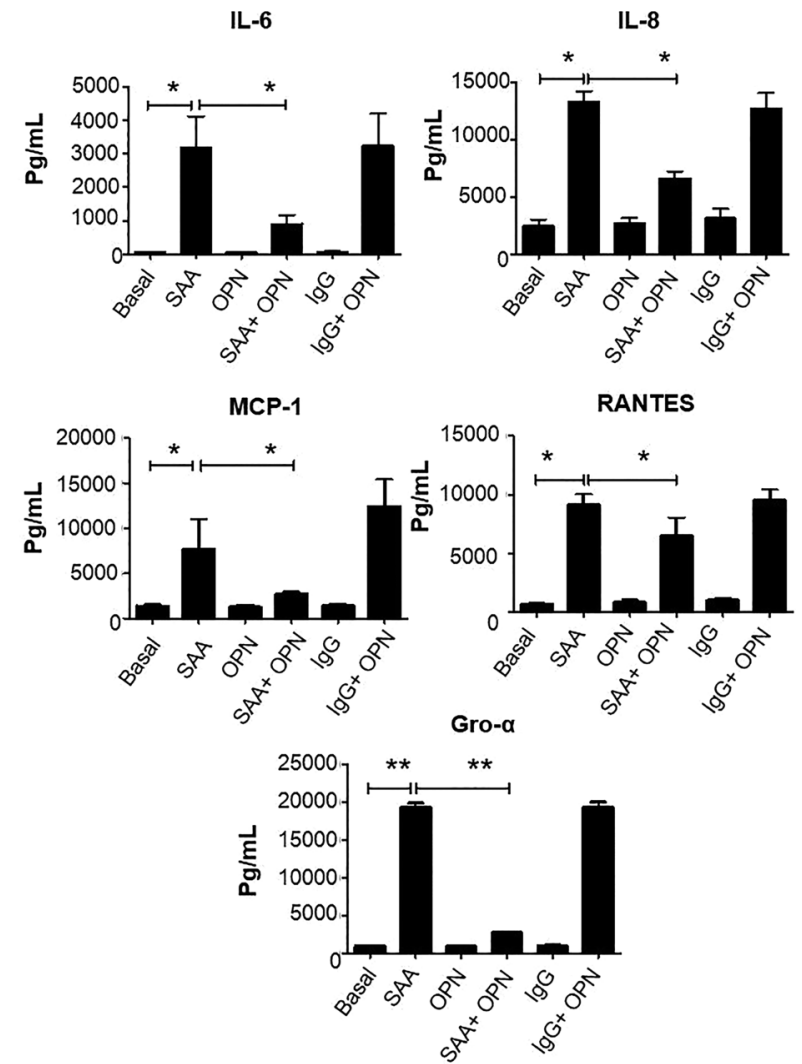

Figure 3 Toll-like receptor 2 (TLR2) mediates acute-phase serum amyloid A (A-SAA)-induced chemokine expression. (A) Rheumatoid arthritis synovial fibroblasts (RASFC) or (B) microvascular endothelial cells (dHMVEC) were stimulated with SAA $(10 \mu \mathrm{g} / \mathrm{mL}$ ) in the presence or absence of OPN301 (1 $\mu \mathrm{g} /$ $\mathrm{mL}$ ) or IgG control $(1 \mu \mathrm{g} / \mathrm{mL})$ for $24 \mathrm{~h}$. Supernatants were harvested and quantified for interleukin (IL)-6, IL-8, monocyte chemoattractant protein (MCP)-1, RANTES and GRO- $\alpha$ by ELISA. Results are shown as the mean \pm SEM $(n=4){ }^{*} p<0.05,{ }^{*} p<0.01$ significantly different. 

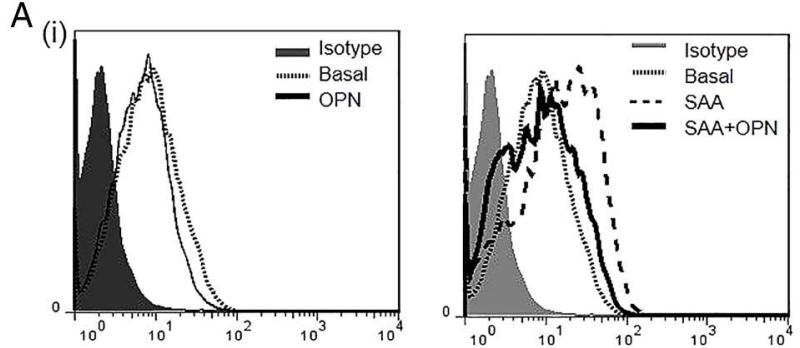

(ii)

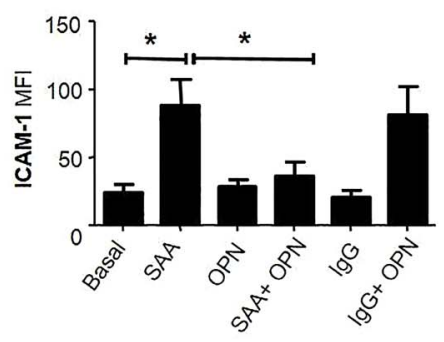

$\mathrm{D}$

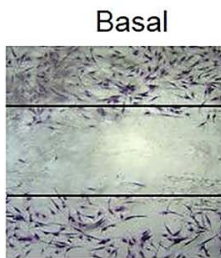

SAA

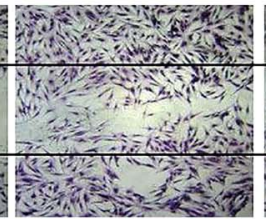

OPN

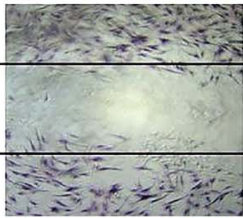

B
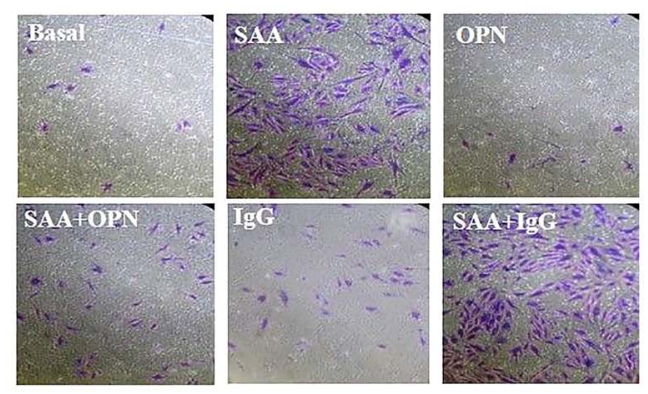

C

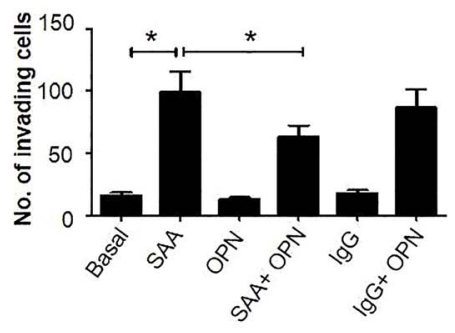

$S A A+O P N$
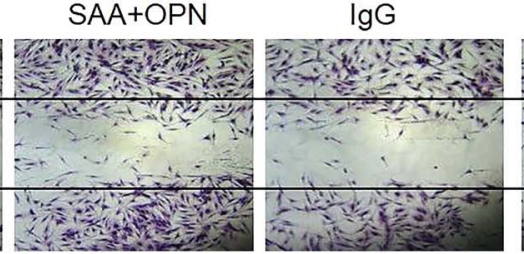

$\mathrm{SAA}+\lg \mathrm{G}$

Figure 4 Toll-like receptor 2 (TLR2) mediates acute-phase serum amyloid A (A-SAA)-induced adhesion, invasion and migration. (A) RASFC were stimulated with A-SAA $(10 \mu \mathrm{g} / \mathrm{mL}) \pm$ OPN301 $(1 \mu \mathrm{g} / \mathrm{mL})$ or $\mathrm{lgG}$ control $(1 \mu \mathrm{g} / \mathrm{mL})$ and expression of ICAM-1 was detected by flow cytometric analysis. (A)(i) Representative histogram showing intercellular adhesion molecule 1 (ICAM-1) on RA synovial fibroblasts (RASFC) following stimulation with SAA $(10 \mu \mathrm{g} / \mathrm{mL}) \pm$ OPN301 $(1 \mu \mathrm{g} / \mathrm{mL})$ for $24 \mathrm{~h}$. (A)(ii) Quantification of ICAM-1 expression in RASFC, data represented as mean fluorescent intensity $(n=5)$. (B) Representative photomicrograph showing microvascular endothelial cell (dHMVEC) invasion. Cells were stimulated with $S A A(10 \mu g / m L)$ in the presence or absence of OPN301 $(1 \mu \mathrm{g} / \mathrm{mL})$ or $\operatorname{lgG}$ control $(1 \mu \mathrm{g} / \mathrm{mL})$ for $24 \mathrm{~h}$. Invading cells attached to the lower membrane were fixed $(1 \%$ glutaraldehyde) and stained (1\% crystal violet) (original magnification $\times 40)$. (C) Bar graph quantifying dHMVEC invasion ( $n=4)$. (D) Representative images showing RASFC repopulating the wound in response to A-SAA $(10 \mu \mathrm{g} / \mathrm{mL})$, an effect that was blocked in the presence of OPN301 (1 $\mu \mathrm{g} / \mathrm{mL})$, with no effect observed for IgG control $(1 \mu \mathrm{g} / \mathrm{mL})(n=3)$. Results are shown as the mean $\pm S E M .{ }^{*} p<0.05$ significantly different.

increased transcript levels of MyD88 in both RASFC (figure 5A) and dHMVEC (figure 5B), reaching maximal levels at 24 and 6 h, respectively. Additionally, A-SAA increased expression of MyD88 protein in both cell types, as demonstrated by western blot (figure $5 \mathrm{~A}, \mathrm{~B}$, ii). In contrast, TNF- $\alpha$ had no effect on MyD88 expression (see online supplementary figure S3).

\section{DISCUSSION}

In this study, we demonstrate that A-SAA is capable of driving NF- $\kappa$ B through TLR2, but not TLR4. At a functional level, A-SAA-induced proliferation, invasion and migration were significantly inhibited in the presence of OPN301 (anti-TLR2) with no effect on TNF- $\alpha$-induced mechanisms. Additionally,
Figure 5 Acute-phase serum amyloid A (A-SAA) induces MyD88. MyD88 mRNA expression was quantified in RASFC and HMVEC following stimulation with A-SAA $(10 \mu \mathrm{g} / \mathrm{mL})$ by real-time PCR. Results are shown as the mean $\pm S E M$ from $n=4$ (HMVEC) or $n=5$ (RASFC) experiments (A, B) (i) Western blot analysis for MyD88 in RASFC A (ii) and dHMVEC B (ii) following A-SAA $(10 \mu \mathrm{g} / \mathrm{mL})$ stimulation for $24 \mathrm{~h}(\mathrm{n}=3)$. ${ }^{*} \mathrm{p}<0.05$, ${ }^{* *} p \leq 0.01$ significantly different.
A (i) RASFC

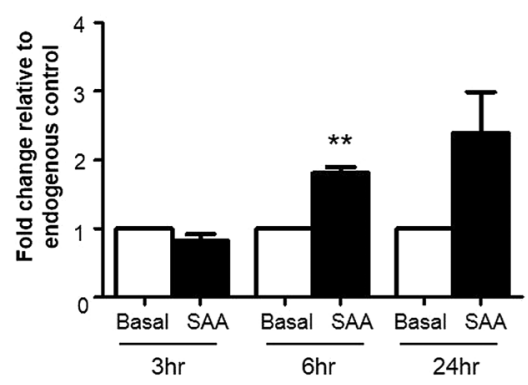

(ii)

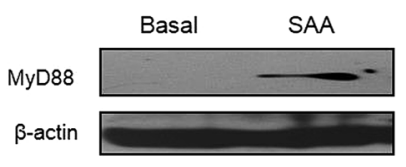

B (i)

dHMVEC

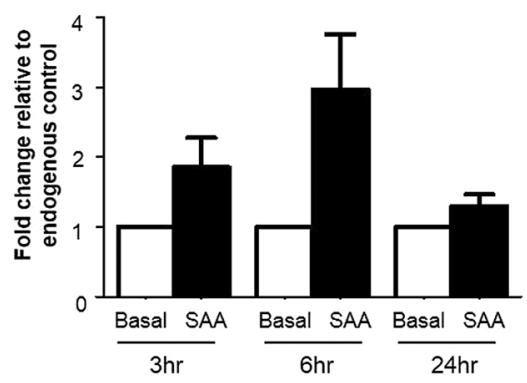

(ii)

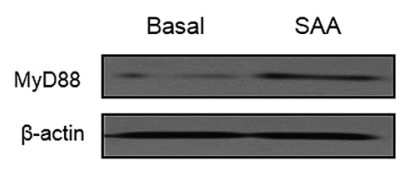


A-SAA-induced angiogenesis, ICAM-1, IL-6, IL-8, MCP-1, RANTES and GRO- $\alpha$ expression in RASFC and dHMVEC were significantly reduced in the presence of OPN301. Finally, we show that A-SAA induces MyD88 signalling in RASFC and dHMVEC. Thus, A-SAA-induced pro-inflammatory mechanisms in RA are mediated, in-part, via the TLR2 receptor.

A-SAA, a major acute-phase protein, is highly elevated both in circulation and locally in tissues during various pathological conditions. $^{12} 39{ }^{40}$ In addition, elevated A-SAA levels correlate with an increased risk of adverse cardiovascular endpoints including myocardial infarction ${ }^{41}$ and is strongly expressed in unstable atherosclerotic plaques. ${ }^{12}$ Additionally, A-SAA plays a central role in lipid metabolism and in acute inflammation, associates with HDL, displacing Apo-AI, resulting in increased HDL saturates, where it renders HDL pro-atherogenic. Furthermore, serum A-SAA levels correlate closely with RA disease activity and can differentiate RA from other arthropathies in a cohort of patients with early arthritis. ${ }^{42}$ Together, this suggests that A-SAA is actively involved in innate immunity and inflammation and suggests a common role for A-SAA as an inflammatory mediator, and an important protein in lipid metabolism and transport.

In this study, we demonstrate that A-SAA-induced pro-inflammatory effects are in part mediated through TLR2 activation with no effect observed for TLR4. Furthermore, we demonstrate in RASFC that A-SAA-induced proliferation, adhesion and migration is mediated by TLR2. Previous in vitro studies have demonstrated the cytokine-like properties of A-SAA, which induces the release of several cytokines in RASFC, dHMVEC, human monocytes and neutrophils. ${ }^{14} 4344$ Furthermore, A-SAA promotes leucocyte recruitment and matrix degradation, key processes in the pathogenesis of RA. $^{18} 1945$ Additional receptors for A-SAA, FPRL-1 and SR-B1 have been demonstrated in the RA joint and mediate A-SAA-induced pro-inflammatory mechanisms. ${ }^{15} 16$

TLRs have been implicated in the pathogenesis of RA with studies demonstrating increased expression of TLR2 in the RA joint, and TLR2 activation in RA synovial explants, RASFC and macrophages. Functional significance of TLR2 has been demonstrated in collagen-induced arthritis models and in TLR2-deficient mice. Several potential TLR2 ligands have been implicated, including heat shock protein/GP96, fibronectin fragments, hyalauronidase oligosaccharides and HMBG-1, all of which are highly expressed in RA synovial fluid. ${ }^{14}$ 46-48 The existence of a ligand is further supported by studies showing that conditioned media from RA synovial explants can activate macrophages in a MyD88 and Mal-dependent manner. ${ }^{30}$ Given that TLR2 is a major pattern recognition receptor, that SAA is spontaneously released from RA tissue and that its functional effects are in part mediated by TLR2, this suggests that SAA may act as an endogenous ligand for TLR2 in the RA joint and contributes to inflammation through persistent activation of this receptor.

We and others have demonstrated A-SAA can directly induce angiogenic processes, adhesion molecules and chemokines expression in vitro and in vivo, ${ }^{14}$ effects that are mediated through FRPL-1 and SR-B1. ${ }^{16} 17{ }^{24}$ However, this is the first study to show a role for TLR2 in mediating A-SAA-induced angiogenic mechanisms. Specifically, we showed that OPN301 significantly inhibited A-SAA-induced tube formation, invasion and chemokine expression. This is supported by studies showing TLR2 activation promotes angiogenesis, cell adhesion and invasion in RA, effects that are in part mediated through the key angiogenic signalling pathway Ang2/Tie2. ${ }^{49}$ In addition, TLR2 is expressed in SM perivascular regions, ${ }^{50}$ and in vitro
TLR2 activation induces VEGF/IL-8 expression in synovial fibroblasts and chondrocytes, ${ }^{51} 52$ and MMP-9 in corneal epithelial cells and THP-1 macrophages. ${ }^{53}$ Furthermore, we have demonstrated using whole-tissue RA synovial explant cultures that OPN301 significantly inhibits spontaneous release of pro-inflammatory cytokines IL- $1 \beta$, TNF- $\alpha$, IFN- $\gamma$ and IL- $8,{ }^{34}$ and MMP-3, MMP-2 and MMP-9. ${ }^{54}$ In addition, culture of RASFC with conditioned media from OPN301-treated RA explants inhibited RASFC migration and invasion compared with IgG control. ${ }^{54}$ Therefore, the ability of TLR2 to mediate A-SAA-induced changes in vascularity, chemokine expression and adhesion further support the hypothesis that A-SAA engages TLR2 to act locally in the RA joint.

Finally, we demonstrated in RASFC and dHMVEC that SAA significantly induced MyD88, an adaptor protein for TLR2. Signalling from MyD88 to the activation NF- $\kappa \mathrm{B}$ and activator protein-1 regulates inflammatory responses and a number of studies have demonstrated induced MyD88/MAL pathway in RA synovial fibroblasts, macrophages and tissue. ${ }^{30-34} 50$ Previous reports have shown that mice deficient for the MyD88 adaptor molecule for IL-1R/TLR signalling failed to develop joint inflammation after induction of streptococcal cell wall arthritis, confirming an essential role for MyD88 in arthritis. ${ }^{53}$ Furthermore, RA synovial explant conditioned media can activate macrophages in a MyD88-dependent manner. ${ }^{30}$ As Myd88-mediated signalling pathways mainly stimulate the activation of $\mathrm{NF}-\kappa \mathrm{B}$, our results suggest that $\mathrm{MyD} 88$ and $\mathrm{NF}-\kappa \mathrm{B}$ mediate the pro-inflammatory and angiogenic functions of A-SAA in RA.

A-SAA has traditionally been viewed as an acute-phase reactant and potential biomarker in inflammation, similar to erythrocyte sedimentation rate or $\mathrm{C}$ reactive protein. In this study, we have described critical pro-inflammatory functions in human cells to suggest that A-SAA is a functionally relevant pro-inflammatory molecule that exerts its effects via TLR2 signalling. The responses to human endothelium and RA cells provide a strong, possibly critical link, between A-SAA and the pathogenesis of vascular and joint inflammation. In addition, these data further support a role for A-SAA in other diseases where high A-SAA expression at site of inflammation has been demonstrated including atherosclerosis, Alzheimer's disease, type II diabetes and metabolic syndrome. ${ }^{8-13} 5556$ A better understanding of A-SAA/TLR2-mediated inflammatory pathways may lead to novel treatment strategies for inflammatory diseases.

Contributors All authors made substantial contributions to the conception or design of the work, or the acquisition, analysis or interpretation of data. All authors were involved in drafting manuscript and approved final version submitted.

Funding This work was supported by the Health Research Board of Ireland and PRTL1. The anti-TLR2 antibody- OPN301 was a gift from OPSONA Therapeutics, Dublin, Ireland.

Competing interests None declared.

Ethics approval St Vincent's University Hospital Ethics Committee.

Provenance and peer review Not commissioned; externally peer reviewed.

\section{REFERENCES}

1 Koch AE. Review: angiogenesis: implications for rheumatoid arthritis. Arth Rheum 1998:41:951-62.

2 Fearon U, Griosios K, Fraser A, et al. Angiopoietins, growth factors, and vascular morphology in early arthritis. J Rheumatol 2003;30:260-8.

3 Cawston TE, Milner JM, Catterall JB, et al. Cytokine synergy, collagenases and cartilage collagen breakdown. Biochem Soc Symp 2003;70:125-33.

4 Mclnnes IB, Schett G. The pathogenesis of rheumatoid arthritis. N Engl J Med 2011:365:2205-19.

5 Nagase H, Kashiwagi M. Aggrecanases and cartilage matrix degradation. Arth Res Ther 2003;5:94-103. 
6 Linke RP, Sipe JD, Pollock PS, et al. Isolation of a low-molecular-weight serum component antigenically related to an amyloid fibril protein of unknown origin. PNAS 1975;72:1473-6.

7 Steel DM, Rogers JT, DeBeer MC, et al. Biosynthesis of human acute-phase serum amyloid $A$ protein (A-SAA) in vitro: the roles of mRNA accumulation, poly(A) tail shortening and translational efficiency. J Biochem 1993;291:701-7.

8 Salazar A, Mana J, Fiol C, et al. Influence of serum amyloid A on the decrease of high density lipoprotein-cholesterol in active sarcoidosis. Atherosclerosis 2000;152:497-502.

9 Kushner I. The phenomenon of the acute phase response. Ann N Y Acad Sci 1982;389:39-48.

10 Urieli-Shoval SLR, Matzner Y. Expression and function of serum amyloid A; a major acute phase protein in normal and disease states. Curr Opin Hematol 2000;7:64-9.

$11 \mathrm{Yu} \mathrm{Y,} \mathrm{Liu} \mathrm{J,} \mathrm{Li} \mathrm{SQ,} \mathrm{et} \mathrm{al.} \mathrm{Serum} \mathrm{amyloid} \mathrm{a} \mathrm{differentially} \mathrm{activates} \mathrm{microglia} \mathrm{and}$ astrocytes via the PI3K pathway. J Alzheimers Dis 2014;38:133-44.

12 Meek RL, Urieli-Shoval S, Benditt EP. Expression of apolipoprotein serum amyloid A mRNA in human atherosclerotic lesions and cultured vascular cells: implications for serum amyloid A function. PNAS 1994;91:3186-90.

13 Husby G, Husebekk A, Skogen B, et al. Serum amyloid A (SAA)- the precursor of protein AA in secondary amyloidosis. Adv Exp Med Biol 1988;243:185-92.

14 Connolly $M$, Marrelli $A$, Blades $M$, et al. Acute serum amyloid $A$ induces migration, angiogenesis, and inflammation in synovial cells in vitro and in a human rheumatoid arthritis/SCID mouse chimera model. J Immunol 2010;184:6427-37.

15 O'Hara R, Murphy EP, Whitehead AS, et al. Acute-phase serum amyloid A production by rheumatoid arthritis synovial tissue. Arthritis Res 2000;2:142-4.

16 Mullan RH, McCormick J, Connolly $\mathrm{M}$, et al. A role for the high-density lipoprotein receptor SR-B1 in synovial inflammation via serum amyloid-A. Am J Path 2010:176:1999-2008.

17 Lee MS, Yoo SA, Cho CS, et al. Serum amyloid A binding to formyl peptide receptor-like 1 induces synovial hyperplasia and angiogenesis. J Immunol 2006;177:5585-94

18 Mullan RH, Bresnihan B, Golden-Mason L, et al. Acute-phase serum amyloid A stimulation of angiogenesis, leukocyte recruitment, and matrix degradation in rheumatoid arthritis through an NF-kappaB-dependent signal transduction pathway. Arth Rheum 2006;54:105-14.

19 O'Hara R, Murphy EP, Whitehead AS, et al. Local expression of the serum amyloid A and formyl peptide receptor-like 1 genes in synovial tissue is associated with matrix metalloproteinase production in patients with inflammatory arthritis. Arth Rheum 2004:50:1788-99.

20 Hershkoviz R, Preciado-Patt L, Lider 0 , et al. Extracellular matrix-anchored serum amyloid A preferentially induces mast cell adhesion. Am J Physiol 1997;273:179-87.

21 Connolly M, Mullan RH, McCormick J, et al. A-SAA regulates TNFalpha and matrix turnover and predicts disease progression in patients pre/post biologic therapy. Arth Rheum 2012:64:1035-45.

22 Connolly M, Veale DJ, Fearon U. Acute serum amyloid A regulates cytoskeletal rearrangement, cell matrix interactions and promotes cell migration in rheumatoid arthritis. Ann Rheum Dis 2011;70:1296-303.

23 Preciado-Patt $L$, Hershkoviz R, Fridkin $M$, et al. Serum amyloid A binds specific extracellular matrix glycoproteins and induces the adhesion of resting CD4+ T cells. J Immunol 1996;156:1189-95.

24 Baranova IN, Vishnyakova TG, Bocharov AV, et al. Serum amyloid A binding to CLA-1 (CD36 and LIMPII analogous-1) mediates serum amyloid A protein-induced activation of ERK1/2 and p38 mitogen-activated protein kinases. J Biol Chem 2005; 280:8031-40

25 He R, Sang H, Ye RD. 2 Serum amyloid A induces IL-8 secretion through a G protein-coupled receptor, FPRL1/LXA4R. Blood 2003;101:1572-81.

26 Xu L, Badolato R, Murphy WJ, et al. A novel biologic function of serum amyloid A. Induction of T lymphocyte migration and adhesion. J Immunol 1995:32:1184-90.

27 Migita K, Kawabe $Y$, Tominaga $M$, et al. Serum amyloid A protein induces production of matrix metalloproteinases by human synovial fibroblasts. Lab Invest 1998;78:535-9.

28 Sodin-Semrl S, Spagnolo A, Mikus R, et al. Opposing regulation of interleukin-8 and NF-kappaB responses by lipoxin A4 and serum amyloid $A$ via the common lipoxin A receptor. Int J Immunopathol Pharmacol 2004;17:145-56.

29 Cheng $\mathrm{N}$, He R, Tian J, et al. Cutting edge: TLR2 is a functional receptor for acute-phase serum amyloid A. J Immunol 2008;181:22-6.

30 Seibl R, Birchler $T$, Loeliger $S$, et al. Expression and regulation of Toll-like receptor 2 in rheumatoid arthritis synovium. Am J Path 2003;162:1221-7.
31 Iwahashi M, Yamamura M, Aita T, et al. Expression of Toll-like receptor 2 on CD16 + blood monocytes and synovial tissue macrophages in rheumatoid arthritis. Arth Rheum 2004;50:1457-67.

32 Brentano F, Kyburz D, Schorr 0, et al. The role of Toll-like receptor signalling in the pathogenesis of arthritis. Cellular immunol 2005;233:90-6.

33 Sacre SM, Andreakos E, Kiriakidis S, et al. The Toll-like receptor adaptor proteins MyD88 and Mal/TIRAP contribute to the inflammatory and destructive processes in a human model of rheumatoid arthritis. Am J Path 2007;170: 518-25.

34 NicUltaigh SN, Saber T, McCormick J, et al. Blockade of Toll-like receptor 2 prevents spontaneous cytokine release from rheumatoid arthritis ex vivo synovial explant cultures. Arth Res Therapy 2010;13:R33.

35 Gao W, Sweeney C, Walsh C, et al. Notch signalling pathways mediate synovial angiogenesis in response to vascular endothelial growth factor and angiopoietin 2. Ann Rheum Dis 2013;72:1080-8.

36 Siednienko J, Gajanayake T, Fitzgerald KA, et al. Absence of MyD88 results in enhanced TLR3-dependent phosphorylation of IRF3 and increased IFN-(beta) and RANTES production. J Immunol 2011;186:2514-22.

37 Fitzgerald KA, Rowe DC, Barnes BJ, et al. LPS-TLR4 signaling to IRF-3/7 and NF-kappaB involves the toll adapters TRAM and TRIF. J Exp Med 2003:198:1043-55.

38 Bowie A, Kiss-Toth E, Symons JA, et al. A46R and A52R from vaccinia virus are antagonists of host IL-1 and toll-like receptor signaling. PNAS 2000;97:10162-7.

39 Libby P. Inflammation in atherosclerosis. Nature 2002;420:868-74.

40 O'Brien KD, Chait A. Serum amyloid A: the "other" inflammatory protein. Curr Atheroscler Rep 2006:8:62-8.

41 Bausserman LL, Sadaniantz A, Saritelli AL, et al. Time course of serum amyloid A response in myocardial infarction. Clin Chim Acta 1989;184:297-305.

42 Cunnane G, Grehan S, Geoghegan S, et al. Serum amyloid A in the assessment of early inflammatory arthritis. J Rheumatol 2000;27:58-63.

43 Furlaneto $\mathrm{CJ}$, Campa A. A novel function of serum amyloid $\mathrm{A}$ : a potent stimulus for the release of tumor necrosis factor-alpha, interleukin-1beta, and interleukin- 8 by human blood neutrophil. Biochem Biophys Res Commun 2000:268:405-8.

44 Patel H, Fellowes $R$, Coade $S$, et al. Human serum amyloid A has cytokine-like properties. Scand J Immunol 1998;48;410-18.

45 Vallon R, Freuler F, Desta-Tsedu N, et al. Serum amyloid A (apoSAA) expression is up-regulated in rheumatoid arthritis and induces transcription of matrix metalloproteinases. J Immunol 2001;166:2801-7.

46 Huang QQ, Sobkoviak R, Jockheck-Clark AR, et al. Heat shock protein 96 is elevated in rheumatoid arthritis and activates macrophages primarily via TLR2 signaling. J Immunol 2009;182:4965-73.

47 Przybysz M, Borysewicz K, Szechinski J, et al. Synovial fibronectin fragmentation and domain expressions in relation to rheumatoid arthritis progression. Rheumato 2007;46:1071-5

48 Yu D, Rumore PM, Liu Q, et al. Soluble oligonucleosomal complexes in synovial fluid from inflamed joints. Arthrtis Rheum 1997;40:648-54.

49 Saber T, Veale DJ, Balogh E, et al. Toll-like receptor 2 induced angiogenesis and invasion is mediated through the Tie2 signalling pathway in rheumatoid arthritis. PLOS ONE 2011;6:;e23540.

50 Radstake TR, Roelofs MF, Jenniskens YM, et al. Expression of toll-like receptors 2 and 4 in rheumatoid synovial tissue and regulation by proinflammatory cytokines interleukin-12 and interleukin-18 via interferon-gamma. Arthritis Rheum 2004;50:3856-65.

51 Cho ML, Ju JH, Kim HR, et al. Toll-like receptor 2 ligand mediates the upregulation of angiogenic factor, vascular endothelial growth factor and interleukin-8/CXCL8 in human rheumatoid synovial fibroblasts. Immunol 2007;108:121-8.

52 Varoga D, Paulsen F, Mentlein R, et al. TLR-2-mediated induction of vascular endothelial growth factor (VEGF) in cartilage in septic joint disease. J Pathol 2006;210:315-24.

53 Joosten LA, Koenders MI, Smeets RL, et al. Toll-like receptor 2 pathway drives streptococcal cell wall-induced joint inflammation: critical role of myeloid differentiation factor 88. J Immunol 2003:171:6145-53.

54 McGarry T, Veale DJ, Gao W, et al. Toll-like receptor 2 (TLR2) induces migration and invasive mechanisms in rheumatoid arthritis. Arthritis Res Ther 2015:17:153.

55 Yang RZ, Lee MJ, Hu H, et al. Acute-phase serum amyloid A: an inflammatory adipokine and potential link between obesity and its metabolic complications. PLoS Med 2006;3:e287.

56 Jernas M, Palming J, Sjoholm K, et al. Separation of human adipocytes by size: hypertrophic fat cells display distinct gene expression. FASEB J 2006;20:1540-2. 